\title{
Therapeutic and prophylactic effects of strontium on radiotherapy-induced skin toxicity in rats
}

\author{
Stronsiyumun ratlarda radyoterapiye bağlı gelișen deri toksisitesinde \\ koruyucu/tedavi edici etkisi
}

\section{Birsen Yücel, Sibel Berksoy Hayta*, Ömer Fahrettin Göze**, Eda Erdiș, Seher Bahar, Mustafa Gürol Celasun, Turgut Kaçan***, Melih Akyol*}

Cumhuriyet University Faculty of Medicine, Department of Radiation Oncology, *Department of Dermatology, **Department of Pathology, Sivas, Turkey ***Afyonkarahisar State Hospital, Clinic of Medical Oncology, Afyonkarahisar, Turkey

\begin{abstract}
Background and Design: This study aimed to investigate whether 5\% strontium (Sr) chloride hexahydrate has preventive or therapeutic effects on the radiotherapy (RT)-induced adverse skin effects.

Materials and Methods: Sixty-four female Wistar albino rats weighing 200-210 g, aged 4.5-5 months were divided into eight groups. Results: There were significant differences between control group and the other groups according to the Radiation Therapy Oncology Group Acute Radiation Morbidity Scoring Criteria (RTOG) and histopathological findings $(p<0.050)$. However, there were no significant differences between RT group and treatment groups ( $p>0.05$ ). In addition, there were no significant differences among treatment groups ( $p>0.05)$. Statistical results were as follows according to the immunohistochemical evaluation of transforming growth factor- $\beta$ : group 1 and 4 ( $p=0.015)$, group 1 and $5(p=0.014)$, group 1 and $6(p=0.035)$, group 1 and $8(p=0.046)$, group 2 and $6(p=0.047)$, group 4 and $6(p=0.031)$; and according to the immunohistochemical evaluation of tumor necrosis factor- $\alpha$ : group 1 and 2 ( $p=0.024)$, group 1 and 8 ( $p=0.045)$.

Conclusion: Topical treatment with $\mathrm{Sr}$ at a concentration of $5 \%$ is insufficient to prevent the side effects of RT involving the skin, as assessed by the RTOG scoring, histopathological findings, and immunological markers.
\end{abstract}

Keywords: Strontium, dermatitis, radiation, skin toxicity

Öz

Amaç: Bu çalışmada \%5'lik stronsiyum (Sr) klorür hekzahidratın radyoterapiye (RT) bağlı gelişen deri toksisitesini önleyici ve/veya tedavi edici etkisinin olup olmadığının araştıııması amaçlandı.

Gereç ve Yöntem: Dört buçuk-beş aylık, 200-210 gram ağırlı̆ında 64 adet, dişi Wistar albino sıçan kullanıldı ve sıçanlar her bir grupta 8 sıçan olacak şekilde rastgele 8 gruba ayrıldı.

Bulgular: Radyo Terapi Onkoloji Grubu Akut Radyasyon Morbidite Puanlama Kriterleri (RTOG) ve histopatolojik bulgulara göre karşılaştırma yapıldığında kontrol grubu ile diğer gruplar arasındaki fark istatistiksel olarak anlamlıydı $(p<0,05)$. Fakat RT grubu ile diğer tedavi grupları arasında istatistiksel olarak fark yoktu $(p>0,05)$. Ayrıca tedavi grupları arasında anlamlı farklılık yoktu $(p>0,05)$. Gruplar transforme-edici büyüme faktörü- $\beta$ 'nın immünohistokimyasal değerlendirmesine göre karşılaştııılığında istatistiki sonuçlar: Grup 1 ve 4 ( $p=0,015)$, grup 1 ve 5 ( $p=0,014$ ), grup 1 ve $6(p=0,035)$, grup 1 ve $8(p=0,046)$, grup 2 ve $6(p=0,047)$, grup 4 ve $6(p=0,031)$ şeklindeydi. Gruplar tümör nekroz faktörü- $\alpha$ 'nın immünohistokimyasal değerlendirmesine göre karşılaştırıldı̆̆ında istatistiki sonuçlar: Grup 1 ve $2(p=0,024)$, grup 1 ve $8(p=0,045)$ şeklindeydi. Sonuç: Topikal olarak kullanılan \%5 konsantrasyondaki Sr RT'nin deri üzerinde yan etkilerini önlemek için yeterli değildir. Bu sonuç RTOG puanlama, histopatolojik bulgular ve immünolojik belirteçlerle desteklenmiştir.

Anahtar Kelimeler: Stronsiyum, dermatit, radyasyon, deri toksisitesi

Address for Correspondence/Yazıșma Adresi: Sibel Berksoy Hayta MD, Cumhuriyet University Faculty of Medicine, Department of Dermatology, Sivas, Turkey Phone: +90 3462581200 E-mail: drberksoy@gmail.com Received/Geliş Tarihi: 25.10.2016 Accepted/Kabul Tarihi: 04.07.2017 ORCID ID: orcid.org/0000-0002-6185-6094

(C) Copyright 2017 by Turkish Society of Dermatology and Venereology

Turkderm-Turkish Archives of Dermatology and Venereology published by Galenos Yayınevi. 


\section{Introduction}

Radiotherapy (RT) is implemented as both therapeutic and palliative treatment in approximately $60 \%$ of all cancers. Controlling the side effects associated with RT, especially with curative application, is important for treatment success. The continuation of the treatment in the programmed manner is essential to avoid resistant clonogenic cells and accelerated repopulation. One of the side effects of the treatment process is seen on the skin, sometimes requires treatment interruption. Side effects of RT involving the skin are typically begin in the second week of the treatment and continue to increase until the end of the treatment. Erythema, edema, and dry and wet desquamations are seen in the early period, while fibrosis, pigmentation disorders (hypo- or hyper-pigmentation), edema, telangiectasia, and ulcers are the adverse effects seen in the late periods. These effects impair the patient's quality of life. Side effects of RT involving the skin are seen in three phases. These phases are regulated by a complex interaction between keratinocytes, endothelium, and fibroblasts.

In phase 1, an inflammatory period begins with epithelial destruction after RT, and neutrophils, macrophages, and lymphocytes accumulate at the injury site. This phase lasts zero to four days, and the mediators secreted from the cells as a result of inflammation are proinflammatory cytokines such as transforming growth factor- $\beta$ (TGF- $\beta$ ), vascular endothelial growth factor (VEGF), tumor necrosis factor- $\alpha$ (TNF- $\alpha$ ), interferon- $\gamma$, interleukin (IL)-1, and IL-8. These cytokines accumulate in the matrix in an uncontrolled way as a result of injury. These mediators play a role in the keratinocyte and fibroblast mitogenesis, keratinocyte migration, angiogenesis, and cellular chemotaxis of fibroplasia.

Phase $\mathbf{2}$ is a proliferative phase and includes reepithelialization and neovascularization. Granulation tissue formation and collagen deposits are present. The factors having role in this phase are TGF- $\beta$, VEGF, epidermal growth factor, fibroblast growth factor, and plateletderived growth factor. Additionally, nitric oxide stimulates collagen accumulation, and thus contributes to wound healing. This phase lasts between three days and three weeks.

Phase $\mathbf{3}$ is the remodeling or maturation phase. It takes three weeks to two years. Matrix metalloproteinases (MMP-1, MMP-2, MMP-12, MMP13, and TIMP) have important roles in this phase ${ }^{1,2}$.

Strontium (Sr) induces neurotransmitter secretion in the nerve endings of the skin (type $C$ nociceptor neurons: sensory nerves), similar to calcium in calcium channels. However, it is less powerful than calcium in the calcium-dependent depolarization ${ }^{3-5}$. On the other hand, it can change the electrostatic region of calcium ion channels, giving rise to stimulation of the unmyelinated sensory neurons and decrease the ionic passage from the channel. Sr has inhibitory effects on neurogenic inflammation ${ }^{3-5}$. Additionally, Sr can directly affect keratinocyte and immunoregulatory cells. It has been shown to decrease TNF- $\alpha$, IL-1, and IL-6 in in vitro cultures ${ }^{5}$. In addition to the effects on the nerve edges, Sr has effects on the inflammatory cell mediators, therefore causing a decrease in inflammation.

Ninety-nine percent of $\mathrm{Sr}$ is found in the bone tissue in the body. Excretion of $\mathrm{Sr}$ from the body occurs through fecal and urinary paths. It was reported in some animal studies that it had adverse effects on bone tissue in high doses (>350 mg/kg). Some studies have reported that there were no side effects at a dose of $40 \mathrm{mg} / \mathrm{kg}^{4}$.
The current study aimed to investigate whether $5 \% \mathrm{Sr}$ chloride has preventive or therapeutic effects on RT-induced adverse skin reactions.

\section{Materials and Methods}

The study was conducted with the approval of Cumhuriyet University Animal Ethics Committee (65202830/50). Sixty-four female Wistar albino rats weighing 200-210 g, aged 4.5-5 months, grown in accordance with the 3Rs tenet (Reduction, Replacement, and Refinement; adopted as ethical principles for experiments on animals in Cumhuriyet University of Medicine Experimental Animals Production and Research Laboratory), were divided into eight groups.

$\mathrm{Sr}$ and $5 \% \mathrm{Sr}$ chloride hexahydrate $\left(\mathrm{SrCl} 6 \mathrm{H}_{2} \mathrm{O}+\right)$ containing an oil emulsion in water were used as topical preparations in the study. An oil emulsion prepared in water without $\mathrm{Sr}\left(\mathrm{SrCl} 6 \mathrm{H}_{2} \mathrm{O}\right.$ -) was used twice a day as a topical preparation in the control group.

The groups are summarized as follows:

Group 1: Control group,

Group 2: RT group.

Treatment groups: Group 3: $5 \% \mathrm{SrCl} 6 \mathrm{H}_{2} \mathrm{O}$ cream was topically applied before RT twice a day for 7 days,

Group 4: Cream without $\mathrm{SrCl} 6 \mathrm{H}_{2} \mathrm{O}$ was topically applied before RT twice a day for 7 days,

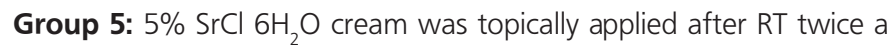
day for 15 days,

Group 6: Cream without $\mathrm{SrCl} 6 \mathrm{H}_{2} \mathrm{O}$ was topically applied after $\mathrm{RT}$ twice a day for 15 days,

Group 7: $5 \% \mathrm{SrCl} 6 \mathrm{H}_{2} \mathrm{O}$ cream was topically applied before and after RT twice a day for 7 days before RT and for 15 days after RT,

Group 8: The cream without $\mathrm{SrCl} 6 \mathrm{H}_{2} \mathrm{O}$ was topically applied before and after RT: twice a day for 7 days before RT and for 15 days after RT. Ketamine $\mathrm{HCl}$ was administered for anesthesia before radiation, measurements of the rats were taken by simulation on the prepared foam assembly, and the arms and legs were fixed with adhesive tape. RT region was established as the skin of the thorax (back) consisting of $10 \%$ of the total body of the rats ${ }^{6-9}$. Maximum two rats were irradiated at one time. Radiations were administered using a Linac device, sized $4 \times 30 \mathrm{~cm}$, with a SSD to a depth of $4 \mathrm{~mm}$, with only a single fraction of the $30 \mathrm{~Gy}$ dose from the only front area, with $6 \mathrm{MeV}$ electron energy, and a bolus of $0.5-1 \mathrm{~cm}$. After application, the groups were divided into separate cages, each of them including a maximum of five rats, and daily care was provided during the time of the study which was completed in the experimental animal laboratory. At the end of three weeks following the first applications, the study was completed, and the experimental animals were given high dose anesthetics (200 $\mathrm{mg} / \mathrm{kg}$ sodium thiopental intraperitoneally). The back skin tissue was dissected and was placed in a sterile container of $10 \%$ formalin. The samples were transferred for pathologic examination after assigning a separate number to a part of each rat.

\section{Test evaluation}

Radiation Therapy Oncology Group Acute Radiation Morbidity Scoring Criteria

The photos of the rats were taken three times (at the beginning of the experiment, beginning of the RT, and at the end of the experiment). 
Clinical adverse skin reactions were graded according to the RTOG scoring criteria ${ }^{10}$. RTOG scoring was made by grading from 1 to 4 .

Grade 1: Follicular, pale, or dull erythema/epilation/dry desquamation/ decreased sweating,

Grade 2: Sensitive or bright erythema, partly moist desquamation/ moderate edema,

Grade 3: Unified, with the exception of skin folds; moist, desquamation, pitting edema,

Grade 4: Ulceration, hemorrhage, necrosis.

\section{Histopathological evaluation}

Skin tissue was stained with hematoxylin-eosin and Masson's trichrome stain. Changes in epidermal thickness, fibrosis, collagen loss, edema, and ulceration were evaluated by a pathologist. The subjects were transferred to the pathology department investigators without group identification. Ten different radiation-induced changes were evaluated in the histopathological examination and one point was given for histopathological changes in each item. Sum of the findings give the total histopathology score s11,12. $^{10}$

Histopathological changes included:

1. Intracellular edema and nuclear pyknosis,

2. Adnexal atrophy or loss of hair follicles,

3. Inflammatory infiltrate in the dermis (may show epidermal permeation),

4. Dilation of some blood vessels; swelling of the others, especially wall swelling of the large vessels in the dermis; endothelial swelling, even thrombosis,

5. Edema of collagen fibers,

6. Degenerative separation of the epidermis in cases that developed blisters,

7. Presence of an ulcer, not only in the epidermis, but also necrosis in the dermis,

8. Neutrophil infiltration around the necrotic areas,

9. Radiation fibroblasts,

10. Vascular changes associated with radiation; congestion.

\section{Immunohistochemical staining}

TNF- $\alpha$ and TGF- $\beta$ evaluation in the skin tissue was carried out by a pathologist.

\section{Statistical Analysis}

Statistical analysis was performed using the SPSS version 15.0 (SPSS Inc., Chicago, IL, USA). Descriptive statistics were used and data were expressed as frequency. Each group was compared with the chi-square test for RTOG scoring, histopathological finding, TNF- $\alpha$, and TGF- $\beta$ levels. A p value of $<0.05$ was considered statistically significant.

\section{Results}

One rat in group 2, 2 in rats in group 3, 2 in group 4, 1 in group 5, 3 in group 6, 2 in group 7, and 4 rats in group 8 died before completing the treatments.

The results of the subjects according to RTOG scoring are shown in Table 1. There were statically significant differences in RTOG score between control group and the other groups, [group 1 and 2 ( $p=0.014)$; group 1 and 3 ( $p=0.003)$; group 1 and 4 ( $p=0.003)$; group 1 and 5 ( $p=0.002)$; group 1 and $6(p=0.005)$; group 1 and $7(p=0.003)$; group 1 and 8 $(p=0.002)]$. However, there were no significant differences between RT group and treatment groups ( $p>0.05)$. In addition, there were no significant differences among treatment groups ( $p>0.05)$. Adverse skin effects in the subjects in groups 1, 2, 5, and 6 are shown in Figure 1. The histopathological results are shown in Table 1 . There were significant differences in the results of histopathological evaluation between the control group and the other groups. $P$ values were as follows: group 1 and 2 ( $p=0.020)$; group 1 and 3 ( $p=0.043)$; group 1 and 4 ( $p=0.014)$; group 1 and $5(p=0.009)$; group 1 and $6(p=0.005)$; group 1 and $7(p=0.003)$; group 1 and $8(p=0.007)$. However, there were no significant differences between RT group and treatment groups ( $p>0.05)$. In addition, there were no significant differences among the treatment groups ( $p>0.005)$.

The results of immunohistochemical evaluation of TGF- $\beta$ are shown in Table 2. When the groups were compared, there were statistically differences in the results of immunohistochemical evaluation between group 1 and $4(p=0.015)$; group 1 and $5(p=0.014)$; group 1 and 6 $(p=0.035)$; group 1 and $8(p=0.046)$; group 2 and $6(p=0.047)$; group 4 and $6(p=0.031)$.

The results of immunohistochemical evaluation of TNF- $\alpha$ are shown in Table 2. When the groups were compared, there was a significant difference between group 1 and $2(p=0.024)$ and group 1 and 8 $(p=0.045)$.

\section{Discussion}

The presence and severity of side effects associated with RT are extremely important especially in curative applications. To complete the treatment without interruption and with minimal side effects is of great importance in terms of treatment efficacy. The control of adverse effects is necessary to avoid accelerated tumor repopulation with the shortness of tumor doubling time in head and neck cancers. Skin reactions are also commonly encountered in RT in head and neck cancer and breast cancer. Current treatments and new agents are being investigated for adverse effects involving the skin in subjects receiving $R T$.
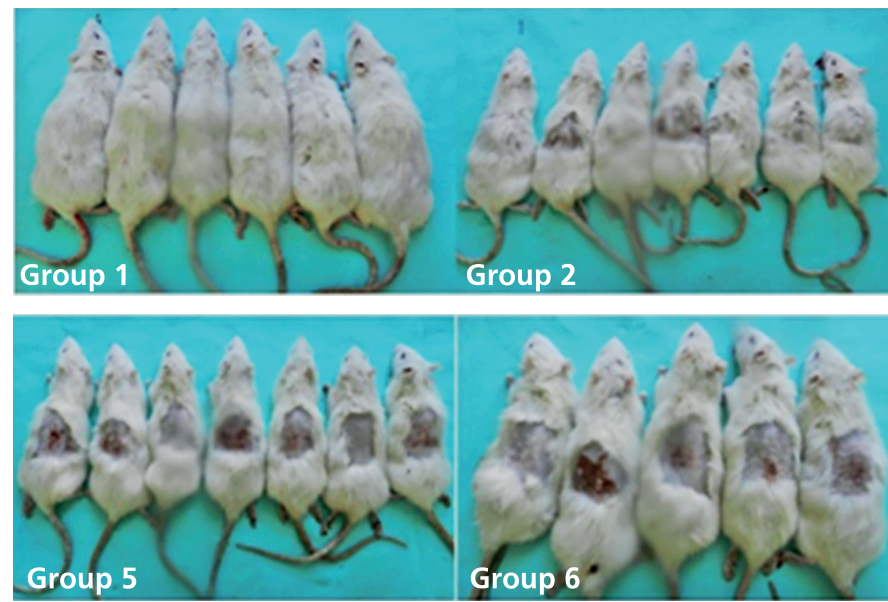

Figure 1. Normal skin findings were observed in the rats in the control group. However, hair loss, hyperemic and dry desquamation, some ulcerated areas were observed locally in the areas of radiotherapy in the rats of the radiotherapy and treatment groups 
Sr affects calcium channels more rapidly than calcium itself ${ }^{13}$. It mimics the effects of calcium on cell growth and cell motility instead of calcium itself ${ }^{3,13}$. It binds to proteins similar to calcium, and interacts with calcium bound ligands ${ }^{4}$. In a study of rats with ulcerative colitis, the cases receiving prednisolone treatment was compared with those receiving lower doses of $\mathrm{SRCL} 6 \mathrm{H}_{2} \mathrm{O}(40 \mathrm{mg} / \mathrm{kg})$ and higher doses of $\mathrm{SRCL} 6 \mathrm{H}_{2} \mathrm{O}(160 \mathrm{mg} / \mathrm{kg})$. Efficacy of treatment was equal between the three groups. Both macroscopic and microscopic effects of SRCL $6 \mathrm{H}_{2} \mathrm{O}$ on wound healing were equivalent to those of prednisone. There was no significant difference in treatment efficacy between low doses and high doses of SRCL $6 \mathrm{H}_{2} \mathrm{O}^{14}$. In this study, side effects of $\mathrm{RT}$ involving the skin were graded according to the RTOG. According to this grading, there was a statistically significant difference between control group and the other groups. However, in the comparison of all groups with each other, there were no significant differences between RT group and treatment groups. In addition, there were no significant differences among treatment groups according to RTOG criteria. There were no positive effects found on clinical improvement in the rats that were topically treated with $5 \% \mathrm{SRCL} 6 \mathrm{H}_{2} \mathrm{O}$, based on the RTOG criteria. In the histopathological examination, there was a statistically significant difference between the control group and RT and the treatment groups. Furthermore, there was no difference in the comparison between RT group and treatment groups treated with using regular creams and

\section{Table 1. Results of subjects according to Radiation Therapy Oncology Group Acute Radiation Morbidity Scoring Criteria scoring and the histopathological findings}

\begin{tabular}{|l|l|l|l|l|l|}
\hline \multicolumn{7}{|l|}{ RTOG scoring } \\
\hline Groups & $\begin{array}{l}\text { Grade 0 } \\
\text { n (\%) }\end{array}$ & $\begin{array}{l}\text { Grade 1 } \\
\text { n (\%) }\end{array}$ & $\begin{array}{l}\text { Grade 2 } \\
\text { n (\%) }\end{array}$ & $\begin{array}{l}\text { Grade 3 } \\
\text { n (\%) }\end{array}$ & $\begin{array}{l}\text { Grade 4 } \\
\text { n (\%) }\end{array}$ \\
\hline Group 1 & $8(100)$ & - & - & - & - \\
\hline Group 2 & $2(29)$ & $3(42)$ & - & $2(29)$ & - \\
\hline Group 3 & - & $1(17)$ & $2(33)$ & $3(50)$ & - \\
\hline Group 4 & - & $1(17)$ & $4(66)$ & $1(17)$ & - \\
\hline Group 5 & - & $2(29)$ & $2(29)$ & $3(42)$ & - \\
\hline Group 6 & - & - & $1(20)$ & $3(60)$ & $1(20)$ \\
\hline Group 7 & - & - & $3(50)$ & $2(33)$ & $1(17)$ \\
\hline Group 8 & - & - & $2(50)$ & $2(50)$ & - \\
\hline Histopathological findings & & & \\
\hline Groups & $\mathbf{0}$ point & $\mathbf{1 - 3}$ point & $\mathbf{4 - 6}$ point & $\mathbf{7 - 1 0}$ point & \\
\hline Group 1 & $3(37)$ & $5(63)$ & - & - & - \\
\hline Group 2 & - & $4(57)$ & $1(14)$ & $2(29)$ & - \\
\hline Group 3 & - & $2(33)$ & $2(33)$ & $2(33)$ & - \\
\hline Group 4 & - & $1(17)$ & $4(66)$ & $1(17)$ & - \\
\hline Group 5 & - & $1(14)$ & $4(57)$ & $2(29)$ & - \\
\hline Group 6 & - & - & $2(40)$ & $3(60)$ & - \\
\hline Group 7 & - & - & $1(17)$ & $5(83)$ & - \\
\hline Group 8 & - & - & $1(25)$ & $3(75)$ & - \\
\hline RTOG: Radiation Therapy Oncology Group Acute Radiation Morbidity Scoring \\
Criteria
\end{tabular}

creams containing SRCL $6 \mathrm{H}_{2} \mathrm{O}$. No histologically positive changes were shown with $5 \% \mathrm{SRCL} 6 \mathrm{H}_{2} \mathrm{O}$ administration.

The clinical effects of ionizing radiation are seen with the release of several mediators at the cellular level. The most marked one of these mediators is TGF- $\beta$. TGF- $\beta$ is released via Smad3 and regulates inflammation and chemotaxis ${ }^{15}$. TGF- $\beta$ stimulates myelofibroblast proliferation and leads to collagen deposit formation in the matrix and has an important role in wound healing via fibrosis ${ }^{16}$. Several studies have reported in vitro and in vivo that, TGF- $\beta$ increases in ionizing radiation in human and mammalian tissues ${ }^{17}$. In the present study, there was no difference between the control group and group 2, which received only RT based on TGF- $\beta$. TGF- $\beta$ was found at higher values in subjects that received cream containing $\mathrm{Sr}$ before RT, compared to the control group, however, this difference was not statistically significant. Therefore, we concluded that the TGF- $\beta$ values in group 3 that used Sr-containing cream seven days before RT, and group 2 that had only $\mathrm{RT}$, were similar to that in the control group. TGF- $\beta$ values in all other groups except these two groups were significantly higher than in the control group. Although there was a statistically significant difference between group 2 and 4 and group 4 and 6, the groups using Srcontaining cream had higher TGF- $\beta$ levels.

Sr can directly react with non-neuronal cells such as keratinocytes or immune regulatory cells ${ }^{14}$. Cytokine release from lymphocytes and the other immune cells occurs from the cell membrane in a calcium dependent manner. An increase in intracellular calcium leads to calcium calmodulin complex formation. Thus, calcineurin activation occurs and

Table 2. Results of subjects according to the immunohistochemical evaluation of transforming growth factor- $\beta$ and tumor necrosis factor- $\alpha$

The immunohistochemical evaluation of TGF- $\beta$

\begin{tabular}{|l|l|l|l|l|l|l|}
\hline Groups & $\mathbf{0}$ & $\mathbf{1}$ & $\mathbf{2}$ & $\mathbf{3}$ & $\mathbf{4}$ & $\mathbf{5}$ \\
& $\mathbf{n ( \% )}$ & $\mathbf{n}(\%)$ & $\mathbf{n}(\%)$ & $\mathbf{n}(\%)$ & $\mathbf{n}(\%)$ & $\mathbf{n}(\%)$ \\
\hline Group 1 & $8(100)$ & - & - & - & - & - \\
\hline Group 2 & $5(71)$ & $2(29)$ & - & - & - & - \\
\hline Group 3 & $2(33)$ & $1(17)$ & - & $2(33)$ & $1(17)$ & - \\
\hline Group 4 & $2(33)$ & $4(67)$ & - & - & - & - \\
\hline Group 5 & $2(29)$ & $2(29)$ & - & $3(42)$ & - & - \\
\hline Group 6 & $2(40)$ & - & - & $3(60)$ & - & - \\
\hline Group 7 & $2(33)$ & - & - & $2(33)$ & $1(17)$ & $1(17)$ \\
\hline Group 8 & $1(25)$ & - & - & $1(25)$ & $1(25)$ & $1(25)$ \\
\hline
\end{tabular}

The immunohistochemical evaluation of TNF- $\alpha$

\begin{tabular}{|l|l|l|l|l|l|l|}
\hline Group 1 & $7(88)$ & - & - & $1(12)$ & - & - \\
\hline Group 2 & $1(14)$ & $3(43)$ & $2(29)$ & $1(14)$ & - & - \\
\hline Group 3 & $3(50)$ & $1(17)$ & - & $2(33)$ & - & - \\
\hline Group 4 & $3(50)$ & $1(17)$ & $2(33)$ & - & - & - \\
\hline Group 5 & $4(57)$ & - & $1(14)$ & $2(29)$ & - & - \\
\hline Group 6 & $2(40)$ & - & $1(20)$ & $2(40)$ & - & - \\
\hline Group 7 & $2(33)$ & - & - & $2(33)$ & $1(17)$ & $1(17)$ \\
\hline Group 8 & - & $1(25)$ & $1(25)$ & $1(25)$ & $1(25)$ & - \\
\hline TGF- $\beta$ : Transforming growth factor- $\beta$, TNF- $\alpha$ : Tumor necrosis factor- $\alpha$ \\
\hline
\end{tabular}


stimulates expression of proinflammatory cytokines such as TNF- $\alpha$ and IL-1. Sr may indirectly decrease TNF- $\alpha$ and IL-1 expression by inhibiting this flow ${ }^{18,19}$. In some studies, it was shown that $\mathrm{SRCL} 6 \mathrm{H}_{2} \mathrm{O}$ suppressed TNF- $\alpha$, IL- $1 \alpha$, and IL- 6 in in vitro cultures ${ }^{3,20-22}$. The main effect of TNF- $\alpha$ is to regulate immune cells, in addition to inducing cell apoptosis ${ }^{23}$. TNF- $\alpha$ plays a key role in wound healing, immune cell regulation, and cytokine release. On the other hand, Sr may have a negative effect on wound healing by reducing TNF- $\alpha$ levels and suppressing the inflammatory step of wound healing. It is also known that glass biomaterials containing $\mathrm{SRCL} 6 \mathrm{H}_{2} \mathrm{O}$ can contribute positively to wound healing via antioxidant effects $^{24}$. Sr cannot show positive clinical and histopathological effects on the tissues with radiodermatitis, which may be due to the severity of radiodermatitis and concentration of the administered treatment.

It was found that Sr blocks TNF- $\alpha$ related to nuclear factor- $\kappa$ B signaling pathway and inhibits the release of inflammatory mediators from monocytes ${ }^{21,25}$. In this study, there were significantly higher TNF- $\alpha$ values between the control group and group 2 that had only RT, and group 8 that had cream application before and after RT. However, the results of the other groups were similar to those of the control group. Low TNF- $\alpha$ secretion was observed regardless of the application time in the groups that had Sr-containing cream and normal cream. This effect was not linked to $\mathrm{Sr}$ as the TNF- $\alpha$ secretion was also reduced in groups that received Sr-free cream.

\section{Conclusion}

Consequently, topical treatment with $5 \%$ concentration of Sr seems insufficient to prevent adverse skin effects of RT. This result was observed in the light of RTOG scoring, histopathological findings, and immunological markers. A higher concentration of topical Sr application in the radiodermatitis model may provide new information to evaluate the efficacy.

\section{Ethics}

Ethics Committee Approval: The study was conducted with the approval of Cumhuriyet University Animal Ethics Committee (65202830/50).

Informed Consent: The study involves animals only.

Peer-review: Externally peer-reviewed.

Authorship Contributions

Surgical and Medical Practices: S.B., M.G.C., Concept: B.Y., M.A., Design: B.Y., S.B.H., Data Collection or Processing: Ö.FG., M.A., Analysis or Interpretation: B.Y., S.B.H., Literature Search: T.K., E.E., Writing: B.Y.

Conflict of Interest: No conflict of interest was declared by the authors.

Financial Disclosure: This study was supported by Coordination Department of Scientific Research Projects of Cumhuriyet University. Project number: T607.

\section{References}

1. Haubner F, Ohmann E, Pohl F, Strutz J, Gassner DG: Wound healing after radiation therapy: Review of the literature. Radiat Oncol 2012;7:162.

2. Goessler UR, Bugert P, Kassner S, et al: In vitro analysis of radiation-induced dermal wound. Otolaryngol Head Neck Surg 2010;142:845-50.
3. Praeger FC, Stanulis-Praeger BM, Gilchrest BA: Use of strontium to separate calcium-dependent pathways for proliferation and differentiation in human keratinocytes. J Cell Physiol 1987;132:81-9.

4. Watts $P$, and Howe P: Strontium and strontium compounds. Concise International Chemical Assessment Document, International Programme on Chemical Safety 77, 2010. Available from: https://www.cabdirect.org/ cabdirect/abstract/20103195727.

5. Hahn G: Strontium is a potent and selective inhibitor of sensory irritation. Dermatol Surg 1999;25:689-94.

6. Jourdan MM, Lopez A, Olasz EB, et al: Laminin 332 deposition is diminished in irradiated skin in an animal model of combined radiation and wound skin injury. Radiat Res 2011;176:636-48.

7. Sugiyama K, Genichiro I, Ochiai A, Esumi H: Improvement of the breaking strength of wound by combined treatment with recombinant human G-CSF, recombinant human M-CSF, and a TGF- $\beta 1$ receptor kinase inhibitor in rat skin. Cancer Sci 2008;99:1021-8.

8. Doctrow SR, Lopez A, Schock AM, et al: A synthetic superoxide dismutase/ catalase mimemtic EUK-2007 mitigates radiation dermatitis and promotes wound healing in irradiated rat skin. J Invest Dermatol 2013;133:1088-96.

9. Thanik VD, Chang CC, Lerman OZ, et al: A novel Mouse of cutaneous radiation injury. Plast Reconstr Surg 2011;127:560-8.

10. Cox JD, Stetz J, Pajak TF: Toxicity criteria of the Radiation Therapy Oncology Group (RTOG) and the European Organization for Research and Treatment of Cancer (EORTC). Int J Radiat Oncol Biol Phys 1995;31:1341-6.

11. Elder D, Elenitsas R, Johnson B, Jaworsky C: Disorders associated with physical agents: heat, cold, radiation and trauma. Lever's Histopathology of the Skin. Ed. Elder D, Elenitsas R, Jaworsky C. 8th, Philadepia-Newyork, Lippincoltt-Raven 1997:311-6.

12. Chu EY: Disorders associated with physical agents: heat, cold, radiation and trauma. Lever's Histopathology of the Skin. Ed. Elder D, Elenitsas R, Rosenbach M, Murphy GF, Rubin Al, Xu X. 11th, Philadepia-BatimoreNewyork-London-Buenos Aires- Hong Kong-Sydney-Tokyo, Wolters Kluwers 2015:404-15.

13. Xu-Friedman MA, Regehr WG: Presynaptic strontium Dynamics and synaptic transmission. Biophys J 1999;76:2029-42.

14. Topal F, Yonem O, Tuzcu N, Tuzcu M, Ataseven H, Akyol M: Strontium Chloride: Can It be a new treatment option for ulcerative colitis? Biomed Res Int 2014;2014:530687.

15. Kim SG, Kim HA, Jong HS, et al: The endogenous ratio of Smad3 and Smad3 influences the cytostatic function of Smad3. Mol Biol Cell 2005;16:4672-83.

16. Martin M, Lefaix J, Delanian S: TGF-beta 1 and radiation fibrosis; A master switch and a specific therapeutic target? Int I Radiat Oncol Biol Phys 2000;47:277-90.

17. Massague J, Wotton D: Transcriptional control by the TGF-beta/Smad signaling system. EMBO J 2000;17:1745-54.

18. Canellada A, Cano E, S'anchez-Ruiloba L, Zafra F, Redondo JM: Calciumdependent expression of TNF- $\alpha$ in neural cells is mediated by the calcineurin/ NFAT pathway. Mol Cell Neurosci 2006;31:692-701.

19. Nachshen DA, Blaustein MP: Influx of calcium, strontium, and barium in presynaptic nerve endings. J Gen Physiol 1982;79:1065-87.

20. Celerier P, Richard A, Litoux P, Dreno B: Modulatory effects of selenium and strontium salts on kerotinocyte-derived inflammatory cytokines. Arch Dermatol Res 1995;287:680-2.

21. Buache $E$, Velard F, Bauden E, et al: Effect of strontium substituted biphasic calcium phosphate on inflammatory mediators production by human monocytes. Acta Biomater 2012;8:3113-9.

22. Fromigue $\mathrm{O}$, Hay $\mathrm{E}$, Barbara $A$, et al: Calcium sensing receptor-dependent and receptor-independent activation of osteoblast replication and survival by strontium ranelate. J Cell Mol Med 2009;13:2189-99.

23. Gaur $U$, Aggarwal BB: Regulation of proliferation, survival and apoptosis by members of the TNF superfamily. Biochem Pharmacol 2003;66:1403-8. 
24. Jebahi S, Oudadesse $H$, Jardak $N$, et al: Biological therapy of strontium-substituted bioglass for soft tissue wound-healing: responses to oxidative stress in ovariectomised rats. Ann Pharm $\mathrm{Fr}$ 2013;71:234-42.
25. Huang C, Li L, Yu X, Gu Z, Zhang X: The inhibitory effect of strontiumdoped calcium polyphosphate particles on cytokines from macrophages and osteoblasts leading to aseptic loosening in vitro. Biomed Mater 2014;9:025010 